\title{
CHRISTEL STALPAERT
}

\section{The Reconfigurative Power of Desire}

\author{
Jan Fabre's As Long as the World Needs a Warrior's Soul
}

\begin{abstract}
Jan Fabre is a Belgian artist who is fond of dismantling the traditional representational codes of theater. His theater work can be 'labeled' as post-representative throughout; it moves beyond traditional representation and Aristotelian dramatic aesthetics. Gilles Deleure's aesthetics of intensities provides an alternative theoretical framework to analyze Fabre's As Long as the World Needs a Wartior's Soul (2000). Since performances like these move away from a cognitively based methodology, traditional semiotics are inadequate to get a grip on them. Deleuze's theoretical framensork proves to be fruitful, for it provides terminological tools such as the Body-without-Organs, rbizomatic bodyscapes, etc. Together with Foucault's discourse theory this terminology gives insight into the biopolitics that are at stake in Fabre's Warrior's. In a most fascinating way, the performance foregrounds the regulating processes of sexual discourses and their suffocating effect on disciplined and normalized bodies - bodies that are molded and fixed to 'fit' into a class, a genus, or a species.
\end{abstract}

Jan Fabre is a Belgian stage director, choreographer, author, designer, visual artist - all of these and more. Sigrid Bousset, a former dramaturge of Fabre's, once noted that some people may resent this: how can someone be equally talented in several different artistic disciplines (9)? But Fabre couldn't care less. He is only interested in transgressing borders, in expressing his own concepts as independently as possible of any constraints, those of specific artistic disciplines included. In an interview for the exhibition catalogue Homo Fabre, he states: "To me there are no limits in any medium [...] I want to work with all possible media and in that way I don't have to be the victim of limitations $[. .$.$] I do not want to$ be a painter, or a performer, or a writer [...] I simply want to do what I like" (24).

Fabre started to create solo performances in Antwerp and Ghent in 1979-1980. His shift towards theater began with Theater Spelled with a $K$ is Tomcat (1981). Curtis L. Carter, who saw the performance at Theater X's Black Box in Milwaukee in 1981, described it as depending on a dialogue of actions similar to the lines of horizontal waves rising and receding as the intensity builds up and subsides (19-20). There is indeed no plot, but a repetition of episodes around a common theme. The titles of his next theater pieces, This is Theatre Like it Was to be Expected and Foreseen (1983) and The Power of Theatrical Madness (1984), both indicate Fabre's fondness for dismantling the traditional representational codes of theater. Fabre's theater work can be labelled as post-representative throughout; it

arcadia Band 40 (2005) Heft 1 
moves beyond traditional representation and Aristotelian dramatic aesthetics. According to Stefan Hertmans, Fabre's theater work seems to refer to "a space in which conflicts, rather than being resolved in a dramatic scheme, are taken back to their inscrutable origin [...]; in his plays there is never any question of an Aristotelian respect for cause and effect, for development and growth of tension, for intrigue or denouement, let alone for catharsis or its derivations. [...] In his work we rarely if ever find the kind of psychologized emotion that we have seen all too often in the theater of identification" $(81,84-86)$.

This is also the case in Fabre's recent As Long as the World Needs a Warrior's Soul (2000). ${ }^{1}$ There is no linear plot line, no logical arrangement of the semiotic signs into a unifying whole. The material renders the spectator perplexed. The performance can only be felt or sensed; it cannot be recognised or explained through common sense. As Francis Bacon says in another context, it "acts directly on the nervous system, rather than passing through the detour of the brain" (18). For this reason, traditional semiotics is inadequate to get a grip on the performance. Gilles Deleuze's aesthetics of intensities provides an alternative theoretical framework to analyze performances like Fabre's Warriors, as it moves away from a cognitively based methodology. In Deleuzian terms, the traditional representation or Aristotelian dramatic aesthetics gives way to an aesthetics of intensities.

\section{Deleuze's Aesthetics of Intensities and Bodyscapes}

Aristotelian dramatic aesthetics is a traditional mental representation that unites the different faculties of a subject (sensibility, imagination, memory, understanding, reason) in a logocentric, harmonious accord. But according to Deleuze's aesthetics of intensities, none of these faculties are in fundamental harmony. They bear witness to a much more complicated network of faculties. Rather than forming a voluntary and harmonious accord, the faculties are in involuntary discord. Each faculty constitutes a field of its own, even though it ceaselessly interrelates with the other faculties. It is only through mental representation and through the presuppositions of both recognition and common sense that the different faculties become attuned to each other. Deleuze defines recognition as "the harmonious exercise of our faculties on an object that is supposedly identical for each of these faculties: it is the same object that can be seen, remembered, imagined, conceived, and so on" (Smith 30). From a representative point of view, the faculty of sensibility can only grasp what other faculties can grasp as well. From a postrepresentative point of view, "what can only be felt or sensed, that which is accessible only to the faculty of sensibility, points to a pure aesthetic

\footnotetext{
1 As Long as the World Needs a Warrior's Soul, premiered on Wednesday, 18 October 2000, De Singel, Antwerp. Programme, s.p.
} 
lying at the limit of sensibility: an immanent Idea or differential field beyond the norms of common sense and recognition" (Smith 34).

An aesthetics of intensity inevitably brings about a reworking of the Cartesian body/mind dualism and how we think about the body. The harmony of the faculties is grounded in the unity of the thinking Subject as disembodied mind. According to Descartes, it is the identity of the Self in the phrase Je pense, donc je suis that grounds the harmony of all the faculties and guaranties the co-ordinating principle of the cogito or reason. ${ }^{2}$ Descartes draws an important conclusion from this: being able to think constitutes our essence as human beings, as disembodied minds:

I possess a body with which I am very intimately conjoined, yet because, on the one side, I have a clear and distinct idea of myself inasmuch as I am only a thinking and unextended thing, and as, on the other, I possess a distinct idea of body, inasmuch as it is only an extended and unthinking thing, it is certain that this I is entirely and absolutely distinct from my body and can exist without it (Descartes 190).

Descartes's dissociation of reason from emotion has diminished the value placed on sensibility, in life as well as in art. In positing the 'clear' and 'distinct' as the highest principle of common sense, as "the light which renders thought possible in the common exercise of the faculties" (Smith 39), Descartes tuned sensibility to understanding. The clear, recognizable concepts that are represented in a work of art reduce the communicative situation to a cognitive understanding or a passive recognition and a 'grasping' of familiar concepts and identities. In tuning body-experiences to the central and co-ordinating faculty of reason, the spectator identifies with the premised fictional characters, the ideas they propagate and their experiences. The represented conflicts occur between closed concepts, between fixed subjects that represent specific identities. The spectator is engaged in processes of territorialisation: in "the reassuring familiarity of encounters with the known" (Patton 8).

Deleuze's aesthetics of intensities pleads for deterritorializing processes that force the spectator to think the yet unthought, to perform "the hesitant gestures which accompany our encounters with the unknown" (Patton 8-9). Deleuze's philosophical writings could therefore benefit from being read together with Spinoza in order to think beyond the Cartesian body-mind split. Deleuze adopts a form of Spinozist materialism in positing equal value between body and mind and he thus dismantles the logocentric paradigm and its predominant Reason or logos. He adopts a Spinozist modesty concerning our knowledge of the human body: we (still) do not know what the human body is capable of: "nous parlons

\footnotetext{
2 "Le Je pense est le principe le plus générale de la représentation, c'est-à-dire la source de ces éléments et l'unité de toutes ces facultés" (Deleuze, Différence et repetition 180). Descartes' disembodied conception of the mind and his argument "Je Pense, donc je suis" can be translated as "That what I can never doubt is that when I think, I exist".
} 
de la conscience et de ses décrets, de la volonté et de ses effets, des mille moyens de mouvoir le corps, de dominer le corps et les passions - mais nous ne savons même pas ce que peut un corps" (Deleuze Spinoza 28).

Deleuze's aesthetics of intensities urges the subject to encounter in wonder what the body is capable of. Deleuze is convinced that the highest function of art is to show, through the means particular to it, what it is to think - what the body and the brain must be for it to be possible to think the unthought. Art then should attain the level at which a work testifies of multiplicity, when it makes vision or language stutter, as if speaking a foreign tongue and saying 'and, and, and' rather than 'or'.

The body should therefore not be defined by genus and species; it should not be understood in terms of form, function and kind (something which does happen in mental representation). The body should be described by the affects it is capable of. A mental postrepresentation does not focus on recognizing the identical, of the analogies within social patterns and principles of classification; it should dare to encounter the field of immanence of the Body-without-Organs in order to encounter difference. The Body-without-Organs is not opposed to the organs, but to the organization of the organs called the organism. The human body is thus not a question of organic organization but of composition; not of development of differentiation but of movement and rest, speed and slowness (Deleuze, Spinoza 166). "The Body-without-Organs consists of dynamic tendencies involving energy transformations and kinematic movements [...] all independent of accessory forms because the organs appear and function here only as pure intensities." (Deleuze A Thousand Plateaux 153) It is no coincidence that Fabre is obsessed with the human body in his postrepresentative theater work. After his trilogy of the body - the spiritual body in Sweet Temptations, the physical body in Universal Copyrights and the erotic body in Glowing Icons - Fabre investigated the possibilities of the body in revolt and rebellion in As Long as the World Needs a Warrior's Soul. In dealing with a Deleuzian aesthetics of intensities Fabre revalues corporeality and the faculty of sensibility within the signaletic material (presentation) and within the spectator (interpretation).

Fabre's Warriors shows the devastating effect of "the pervasiveness of the computer metaphor of the mind"; i.e. the downplaying of emotional and aesthetic life in our culture (Lakoff and Johnson 401). He shows the regulating processes of sexual discourses and their suffocating effect on disciplined and normalized bodies, bodies that are moulded and fixed to 'fit' into a class, a genus, a species. Yet, Fabre traces countermovements of the body in revolt and rebellion.

\footnotetext{
3 "Chaque lecteur de Spinoza sait que le corps et les âmes ne sont pas pour Spinoza des substances ni des sujets, mais des modes. [...] un mode, c'est un rapport complexe de vitesse et de lenteur, dans le corps, mais aussi dans la pensée, et c'est un pouvoir d'affecter et d'être affecté, du corps ou de la pensée."
} 
"The body presents its individuality and singularity against a process of dehumanization." (Fabre, As Long as s.p.)

The violence of Fabre's Warriors does not result from a war that is waged on stage, but from a conceptual deterritorialization, from an encounter with new bodily space. According to Deleuze, "there is a violence of what comes before the formation of codes and subjects, which is a condition in an expressive material of saying and seeing things in a new way" (Rajchman 124). Fabre attempted to discover a similar non-illustrative violence of bodily space, prior to signification and subjectivity. The Warriors in the title of the performance refer to these bodies that protest and revolt against the normalizing and disciplining mechanisms of society. Fabre presents images of guilt and penance, of discipline and punish, and has these collide with images of resistance and revolt, with images of affection. And as this conceptual war is waged, new bodyscapes emerge.

\section{Images of Guilt and Penance}

The opening scene of Warriors presents a stage filled with Barbie and Ken dolls. Their identical and 'perfectly' proportioned bodies are lined up symmetrically. A naked man and a naked woman dissociate themselves from the strictly ordered pattern. They bow their heads when they are next to one another, as if they are ashamed of something. A bunch of obscure figures initiate a harsh questioning"Did you do it?" - alternatingly hissing, whispering, crying, raging and raving. This scene reminds us of the second part of Jan Lauwer's Snakesong-trilogy, Leda/Le Pouvoir (1995), where the first act contains a similar cross-examination of two young people. Both scenes refer to the biblical story of the original sin, but they have different effects. While Lauwer stages a long, complex and almost hopeless situation, Fabre's examiners react in an indifferent, almost relieved way to the confession of the sexual crime of the two accused - "So what? No big deal!" Hendrik Tratsaert's comment on this paradox in the program of the performance was: "Paradise lost? Paradise regained?" (s.p.)

In his Histoire de la sexualité Michel Foucault interpreted 'confession' and 'examination' as two important technologies of bio-power that regulate the human body and mould it into the dominant sexual discourse. Sexuality is caught in a system of codification that is based on avowal. The subject who confesses, the sinner, is firmly (re)positioned in his/her inferiority within power relations. The examiner turns the confessant onto the right track within dominant discursive formations:

on n'avoue pas sans la présence au moins virtuelle d'un partenaire qui n'est pas simplement l'interlocuteur, mais l'instance qui requiert l'aveu, l'impose, l'apprécie et intervient pour juger, punir, pardonner, consoler, réconcilier (Foucault, Histoire de la sexualité 83).

It seems that Fabre's Warriors questions the all-embracing power of 'confession' and 'examination' as a technology of bio-power. The ease with which the sin is 
forgiven in the opening scene reveals cracks in the solemn discursive ritual and in the solid linear-successive structure of 'judgment', 'remission', 'consolation' and 'reintegration in the dominant discourse'. The hope for effective individual resistance appears in these cracks. The relief after the confession of the sexual crime for which the two young people are committed for trial in Warriors sets the tone for the rest of a performance that took the notions of protest and resistance as its starting point.

\section{Images of Discipline and Punishment}

The next scene, though, is rather disenchanting and disillusioning. All hope for effective individual resistance is tempered by the overwhelming images of discipline and punishment. The actress Els Deceukelier cries like a little child as she does not have the same beautiful breasts, the same long legs, the same long hair and the same smooth skin as her Barbie-doll. She covers herself with margarine to give her skin the same plastic appearance and marches across the stage as if she were a mechanical puppet. The other dancers and actors attempt to imitate the pose of their twin Barbie or Ken doll. Their repeated attempts evoke feelings of disgust, aversion and reluctance while some obscure leading figures reshape the Barbie and Ken dolls into 'impossible' positions before throwing them on the ground. When the imitations of the actors/dancers are not carried out correctly, the leading figures stretch parts of the other's human bodies until they are. This is a painful undertaking but the actors/dancers keep smiling. A housewife looks scornfully around her, at the mess of chocolate spread, ketchup and butter on the floor and on the bodies of the other dancers/actors, and praises a doll for being clean, for never smelling, sweating, nor urinating. Neatness and cleanness are debunked as narrow-minded ideals.

Fabre shows how mannequin-society turns the body into a battlefield on which a war is waged between the corporeal body and the ideal body. In the end, the life of a perfectly disciplined woman is a lifelong battle against natural hair growth at undesirable places, against natural but inconvenient smells, against natural but undesirable layers of fat, etc. The scenes form an obvious reference to the manipulative power of ideal images of femininity and masculinity in the process of subjectification. They confront the spectator with the incessant and increasing, but pointless efforts of a disciplined and normalized body to comply with the 'ideal' image. These images of discipline, punishment and bodily hygicne are cast alongside the monologue Io, Ulrike, grido (I, Ulrike, cry out) by the Italian writer Dario Fo. The actress Anny Czupper verbalizes the revolt and the political activities of a German RAF-activist who was put into prison. Ulrike Meinhof's testimony on how her imprisoned body was being disciplined and punished by 'the tyranny of hygiene' and her protest against 'clean' social democracy is touching: 
My body is like washing-powder, scattered and dispersed in this giant centrifugal machine, called prison. [...] I have to get myself together again. I gather the parts, put them back together again, recomposition. I have to offer resistance ... I have to keep on resisting ... I won't let them drive me mad. I have to think, reflect upon it. So I think, right, I think about you and your methods of torture, how you press your noses against the walls of this aquarium. [...] You put me in this aquarium because I won't bend, because I refuse to be like your women, wrapped up in cellophane. (Theater program: s.p.)

Meinhof realizes that by torturing her - by means of sensory deprivation in a hyper-structured panopticon, in the antiseptic hell of prison - the guards are trying to break her, to drive her mad, to drive her to suicide. She offers resistance; in order to break her will they have to kill her: "very clean, like the whole social democracy". Ulrike Meinhof died in prison in 1976; the suspicious circumstances remain unsolved.

According to Foucault, the techniques of subjectification (assujettissement) can only be understood in the light of the regulating practices of certain forms of knowledge. Every human being becomes a subject by entering the system of a specific discourse. A subject is put in its (proper) place and at the same time derives its specific identity and its relative independence from that place. Foucault considers the body as a site of power, inhabited by a play of forces aiming both at discipline and resistance in the production of subjectivity. Surveiller et punir (1975), Foucault's study of the prison system, traces the transition from a punitive society that considered the body as an object to be corrected and punished, to a regime of reasoned manipulation and discipline. In staging Ulrike Meinhof's monologue in this particular manner, Fabre describes the specific technology of controlling the subject in terms of discipline and punishment, both in a concrete and an abstract sense. The body is both the object and target of power: it is "a body that is manipulated, shaped, trained, which obeys, responds, becomes skilful, and increases its forces" (Foucault in Braidotti 78).

In Foucault's La volonté de savoir (1976) the specific technology of control of the subject via sexuality is described in terms of regulation, not discipline and punishment. Hence the discourse of sexuality no longer deals exclusively with 'negatively' connoted subjects, the so-called insane and criminals who are separated from the 'sane' and the 'good' in society and are put away in madhouses and prisons. Similarly, Fabre's Barbie- and Ken-like actors and actresses are regulated by a discourse of hygiene and sexuality that no longer normalizes 'deviant' subjects; it appears to be 'all-embracing' and constitutional of all subjects in society. It is not a mere matter of repression; the discourse of sexuality is rather a condition for experiencing sexuality. The mechanisms of power are thus not concerned with creating systems of knowledge, but with legitimating the 'truth'.

Foucault considers a critical analysis of the interaction or networks of power and knowledge as the first step of (political) agency in order to produce strategies of resistance. It is important to draw maps or cartographies of these networks, to render them visible, so as to identify possible points of resistance. In 
trying to elaborate a new ethics, Foucault's tactic with regard to sexuality is then "to isolate the modalities of control that the subject exerts on himself [...], in his vital and impassable relation to the other" (Braidotti 91). Fabre isolates representations of such modalities of sexual and bodily control and regulation on stage. The Barbie-dolls on stage and the desperate attempts of the dancers/actors to imitate the idealized positions and physical structure or exterior appearances of these dolls does not only uncover the hollowness of the 'ideal' body, of the imago that is highly valued in our contemporary mannequin-society, it also uncovers the manipulative power of the mirror, the reductive mechanism of representation in thought, and the tyranny of the eye in our own visual practices.

\section{Images of Resistance and Revolt}

Foucault's ultimate aim in drawing maps or cartographies of the networks of power and knowledge is to locate possible points of resistance. For Fabre, as well as for Foucault, the corporeal subject is a site of control but also and at the same time a site of strategies and resistance. It is Fabre's aim to commit a bank raid in a place that - following Foucault's panopticon - is structured like a perfect prison.

For a long time, 'Surveiller et punir' by Michel Foucault was my greatest source of inspiration. The way in which everything is structured in space, from the point of view of the perfect prison, with the position of the king seeing everything; what happens between bodies, between subjects. [...] And at the same time, the training of my 'warriors of beauty' - as I sometimes call my actors and dancers - from time to time resembles a bank raid. (Fabre, As Long as s.p.)

But Fabre does not carry out a bank raid merely for the kick. This bank raid is carefully planned and several strategies are worked out beforehand. A map is drawn of the building, its structure, and its powerful mechanisms of defense, etc. Fabre is driven by the desire somehow to find the right combination to the safe.

You enter a bank to break into the safe; you are intensely aware of every sound, every move, every position and posture of your body. You register the slightest sensation, the slightest perception. You listen, you unscrew the bolts, you try to open the lock, you try to find the right combination. (Fabre As Long as s.p.)

Knowing and thinking precede 'resistance', 'revolt' and 'battle'. Drawing maps or cartographies of the networks of power and knowledge is an act of resistance in itself, not because nobody knew anything about it till now, but because it is the first reversal of power, the first step towards more action against the mechanisms of power. The moment one starts to talk about the network of power and knowledge, one tackles it, by calling things by their name, by saying who is doing what, by pointing out an assumed end or result. (Foucault, Raster 133)

Fabre is not naive, though. He realizes that his desire to find the right combination will never be fulfilled. But he cherishes the hope that this desire 'moves' 
something in society, that it finds its place in the silent changeability and the internal dynamics of culture:

Of course you will never find the right combination, because everything goes wrong, because someone enters the room and you have to sneak away. But it has everything to do with the training of the actors and the dancers; to create something together, to tackle a problem, to deal with a solution, to gather knowledge. To be on one's guard, to have a strategy - in body and in mind. (Fabre, As Long as s.p.)

Fabre tries to locate agency by means of the arts, by means of his embodied warriors of beauty - in body and in mind -, by means of an aesthetics of intensities, even though he knows that this won't have a direct impact and will not reveal a clear solution in real life. But this doesn't matter. The individual warrior is not defeated as long as the silent changeability and the intern dynamics of culture provide room for this kind of revolt that surpasses passive resistance. Following Frederic Jameson, Fabre sees cultural objects as specific sites on which social issues are discussed and fought for. Taking into account the post-modern concept of time and space, he values art less for its everlasting value, than for its instantaneous function in society, i.e. in the individual life of those who encounter it in a specific here and now. It is according to a similar 'one-man move', to this individual battle of the moment that Fabre tries to push back the borders of discursive formations. In other words, the warrior in Fabre's As Long as the World Needs a Warrior's Soul is not a member of a political party, or of another closed social grouping. He/she does not operate in a political or engaged theater in the traditional meaning of the word. The actor/actress does not render anything visible, his/her individual battle does.

Deleuze likewise believes in the reconfigurative power of the arts. He believes that great artists are also great thinkers; art is also a creative enterprise of thought, one that renders visible. The philosophical concepts of Nietzsche should be made thinkable in the arts: "La recherche de nouveaux moyens d'expression philosophiques fut inaugurée par Nietzsche, et doit être aujourd'hui poursuivie en rapport avec le renouvellement de certains autres arts, par exemple le thêâtre ou le cinéma." (Deleuze, Différence et Répétition 4) Smith aptly remarked in this context that modern art and modern philosophy both renounced the domain of representation and instead took the conditions of representation as their object (Smith 40). Fabre's theater work takes the conditions of ideal bodily representations as his object. In doing so, he does not render the visible. He renders visible. He aims not at the reproduction of ideal bodily images but at the presentation of the non-visible mechanisms and forces that act behind or beneath these forms. 


\section{Pleasure or Desire}

Pleasure and desire prove to be two philosophical concepts of essential value in the location of resistance and reconfiguration within the disciplined and normalized body. Foucault and Deleuze have a different appreciation of these terms, though.

In the first part of his Histoire de la sexualité Foucault called for a reconfigurative practice by conceptualizing the liberating aspect of pleasure (plaisir). He considered corporealities and the concept of delight or pleasure (corps-plaisirs) as forming a possible loophole of escape from dominant discourse because sexuality is the motor of biopolitics. On the other hand, Foucault rather disliked the concept of desire (désir) because it always requires the preposition 'for' and thus presupposes a lack.

Deleuze elaborated on Foucault's concept of plaisir, but preferred the term desire (désir). The difference in appreciation is more than a mere matter of terminology. It concerns a fundamentally different concept of the mechanisms of power and resistance in society. Deleuze said in an interview that for him "society is a fluid. It is truly a fluid - or even worse, a gas. For Michel [Foucault] it was an architecture" (Deleuze, History of the Present 21). This reveals Foucault's top-down and Deleuze's bottom-up way of thinking. Foucault was surprised that - despite of the 'all-embracing' effect of power - subjects kept on resisting and revolting. Deleuze, on the other hand, was convinced that society kept on leaking in an ideological sense of the word - it was after all a fluid or a gas. He was surprised that society managed to keep stopping up the leakage and install a certain kind of unity in thought. Deleuze and Foucault are thus concerned with the same philosophical concepts - i.e. the regulating mechanisms that chain the body - but they approach these concepts from opposite directions. In contrast to Foucault, Deleuze considers the concept of desire to be prior to the concept of power: "le pouvoir est une affection du désir" (Deleuze, Magazine littéraire s.p.). In other words, the lines of flight are prior to the normalizing principles of a dominant discourse; "la première donnée d'une société est que tout y fuit, tout s'y déterritorialise" (Deleuze Magazine littéraire s.p). To resist or to revolt is then to (re)open a line of flight that has always been there, but remained invisible up to then.

The terminological dispute concerning 'desire' and 'pleasure' results from these opposite ways of approaching the concept of the disciplined body. Foucault disliked the word 'desire' because it connoted a certain lack; it had always been used in connection with repression, discipline and punishment. Deleuze, on the other hand, disliked the word 'pleasure' because it seemed to interrupt the plane of immanence that is characteristic for his concept of (positive) desire. He considers 'pleasure' as a static concept, as a tendency towards 'being' rather than 'becoming', whereas 'desire' implies a perpetual moving forwards, a 'becoming': 
le plaisir vient interrompre la positivité du désir et la constitution de son champ d'immanence. [...] Le plaisir me parait le seul moyen pour une personne ou un sujet de "s'y retrouver" dans un processus qui la déborde. C'est une re-territorialisation. (Deleuze, Magaz̧ine littéraire s.p.)

Deleuze assures Foucault that he does not use the word 'desire' as it was used by Freud or Lacan. Its value is not found in the objects of desire, but in the activity of desire. His concept of 'desire' has nothing to do with lack. It implies a plane of immanence or a Body-without-Organs that is not defined by genus and species, nor conceived in terms of form and function. The Body-without-Organs is not a matter of the organism - which Deleuze understands as "the judgemental organization of the organs - [...] [It is] the body insofar as the body can be thought and lived as a dynamic system of non-subjectified affects and powers" (Gatens 167). Deleuze's concept of desire does not impose a plane of organization, but rather posits a plane of immanence. Within this plane of immanence Deleuze distinguishes vectors of reterritorialization and deterritorialization.

In Foucauldian terms, mechanisms of power will constitute, normalize, discipline and regulate. Deleuze's reading of Spinoza posits a rather different 'social cartography' in the sense that it maps individuals onto a plane of immanence by means of vectors of deterritorialization and (re)territorialization. These vectors are autonomous, but at the same time interwoven with one another, as in a rhizome. They both operate on physical bodies and involve material investments of energy, speed and affects. Vectors of (re)territorialization organize the body. The prefix 're' points to the affirmation of rules and norms of behaviour and action. Conversely, vectors of deterritorialization designate the process of freeing the body from pre-programmed representations, forms and functions. Deleuze considers desire as a possible vector of deterritorialization or a line of flight (ligne de fuite); a loophole that allows us to experiment with ourselves as a Body-without-Organs.

Fabre likewise locates the reconfigurative power of the body in desire. The individual bodies of the dancers and the actors posit a plane of experimentation within a plane of organization. During the seminar New Concepts of Theatre, which was organized by the University of Antwerp in the context of the Dutch-Flemish Theatre Festival, Fabre said that his theater was all about territory. He creates topographies to wage war upon, thus touching Deleuze's concept of deterritorializing lines of flight that intersect the social field as on a map.

For the structure of the theatrical space Fabre was inspired by the composition of the painting Pier and Ocean by Piet Mondrian, which is composed of horizontal and vertical lines and planes of primary or black and white colours. Fabre approached the theatrical space from the ideal spectator's point of view and positioned his actors and dancers symmetrically in straight lines. His dancers follow the rigid geometrics of Cubism and connected movements from classical academic ballet with military discipline and martial arts to trace the network of vectors of territorialization. 
To create this strictly ordered pattern, Fabre applied the strategy of grouping according to form, kind and function; a strategy that humans have adopted to create hierarchies within groups of people with recognizable forms of behaviour. These groups generally consist of a single leader who decides whether or not to attack the other groups in order to conquer territory. Fabre let his dancers move like a Grecian phalanx that advances upon the audience, dancing forward and backward, as if in a line of battle. "The Grecian phalanx is not by chance a formation of troops of the line in war [...] I call it a military dance." (Fabre, As Long as s.p.)

Working within this strictly ordered pattern, Fabre sought out the spontaneous, positive desire of his dancers. To create these vectors of deterritorialization, he used the individual bodies(-without-organs) of his warriors of beauty, their individual material investments of energy, speed and effect. In other words, he looked for individuality within the group, for the corporeal body in motion, for its speed, its slowness and its energy that exceed all principles of classification. Fabre traced vectors of deterritorialization in order to unravel riddles, in order to render audible the unspeakable, to render visible the invisible, to think the unthinkable: "I am fascinated by riddles; by the things people can't read, can't write, can't draw. I consider that to be the reason for my being an artist" (Fabre As Long as s.p.).

The movements taken from classical academic ballet, military discipline and martial arts are obviously performed by trained and disciplined bodies. The dancer Lisbeth Gruwez experienced, though, that it is not easy to dance within a Grecian phalanx. "You cannot dance scheming and craftily up there. You cannot take up your position in a reposed manner. It is as if you are dancing in sewage, because the floor is very dirty. You have to fight for your balance and your position. [...] One has to get up and fight back." (Theater program, s.p.) So instead of representing a solid, uniform and perfectly disciplined group of emotionless dancers, Fabre reveals the individual sweating, falling, failing and recovering of bodies. These bodies slow down or speed up according to their level of energy. Some bodies tear themselves away from the disciplined group to open up a line of flight; 'failure' can be productive.

In this context, one specific solo performance by Lisbeth Gruwez is very touching. It stemmed from an improvisation on desire. Gruwez is dressed in a clean, white suit and makes vibrating movements with her hips; sometimes uncontrolled and spastic, sometimes slow and stylized, but without any interruption and with a nob of butter in her mouth: "I tried to come like a man in the body of a woman. It had to be like a ritual. During that solo I suffer and fight back. Like a flower that wants to grow in my womb, despite the mud. Someone who is hurt can become a warrior." (Theater program: s.p.)

The climax of this movement of suffering and fighting back is visually supported by the similar movements of Els Dekeukelier who is covered with choc- 
olate spread to represent an icon of Billie Holliday. Earlier in the performance we heard her sing the bitter protest song Strange Fruit (1940) about seeing her own father being lynched during Apartheid. At that moment in the performance, she was immobile like the statue of a broken woman. She was a construction, paralyzed by white power. Now, we experience the strength of the deterritorialising movement of the African woman; the 'typical' pulling back of the elbows and the stamping of the feet are performed parallel with the spastic-stylized movements of Gruwez and form an image of resistance. Both bodies are marked by the scars of discipline and punishment, but at the same time they manifest reconfiguration and deterritorialization.

These two warriors of beauty are small, ordinary people who perform their individual resistance by means of their own body and by the desire and effects it produces. These warriors express their revolt and resistance by means of a Deleuzian deterritorialization. The individuals recapture the territory of their own corporeality from the mind, which had reigned supreme till that moment. There is an encounter with a new, unknown bodily space - for the spectator as well. Warriors stimulates a revaluation of corporeality and of the faculty of sensibility, for it stimulates the spectators as viewing subjects to reconsider their cognitive functions, visual practises, and mental representations with regard to their bodies. It is more a kind of minor or foreign visual idiom in what we have been accustomed to see, also as far as 'moving' bodies is concerned. The performance does not represent a certain type of body. It rather produces affects that provoke the viewers and forces them to reconsider fixed gender-identities and ideal subjects.

\section{Images of Affection}

Fabre's 'warriors of beauty' are not like the traditional heroes who appear in mythological stories and fairy tales that defeat monsters and free princesses. The violence that explodes on stage is not the effect of a narrative or conceptual conflict that has to be solved. The physical deterritorializing movement of the dancers/actors is thus not reduced to a 'narrative' movement. It is not canned in a traditional, Aristotelian dramatic structure, with a clear logical development and growth of tension. The signaletic material that Fabre fires at the audience involves images as non-causal becomings, images that carry their own negation within them. This means that the spectator is no longer guided towards the tight interpretation by cognitive understanding, by a 'clear' and 'distinct' narrative plot. In Fabre's theater the traditional paradigm of focused, cognitive vision has yielded to a multi-perspective aesthetics of intensities. Narration no longer operates as an all-embracing, coordinating principle. The spectators are thrown back on their own resources, on their individual sensory experience and on the internal rhizomatic composition of the piece. 
All matter is image [...] the universe is defined as the whole aggregate of images acting and reacting to one another on all their surfaces and in all of their parts. In this holistic picture, interiority and exteriority are only relations among images. [...] Body and brain are Images in the sense of their being receptive surfaces acting and reacting to the propagation of energy and the force of matter. (Rodowick 28)

In the rhizomatic signaletic material of Warriors, a sign does not meet its equivalent in language, but in thought: "The theory of signs is logic, not linguistics. The brain is the screen" (Bensamaïa and Toufic 15). The signaletic material of Warriors is put next to, on top of and against itself. Fabre flanks, confronts, assembles, samples, and superimposes images within the internal, rhizomatic structure of his play. The meaning he attributes to images and signs is mobile and in perpetual becoming. It moves and changes in its contact with other images and signs, independent of a co-ordinating narrative plot.

A guy from the Deep South reproaches his wife - in fact an over-sized Barbie doll - of flirting with "those nigger boys". His accusations reach their climax when he harshly cuts her long, blond hair. The destruction of one of her attributes of seduction initially provokes laughter. The grotesque gestures and the exaggerated American accent provide a moment of emotional rest for the spectator who has had to cope with harsher and more tragic images than that. But all of a sudden, the image of the character collides with the words that are being shouted by the other actors on stage. Racist slogans about Jews flank the image of the guy from the Deep South who is still maniacally cutting his wife's blond hair. The 'funny' image of the pile of hair now excites feelings of disgust because it is associated with the close-cropping of the Jews by the Nazis in the concentration camps. The reference to the extermination of the Jews, labelled as the antipodes of the ideal image of the Aryan race of that time, has a knock-on effect in changing the mechanisms of meaning. The discourse of bodily hygiene changes into an ideology of purity that can take on dangerous racist proportions. The shower cabinets at the back of the stage - where the actors and the dancers take a shower from time to time to remove the ketchup, butter and chocolate spread from their bodies - change from having a practical function and from being a pendant of (the tyranny of) corporeal hygiene to being sharp reminder of the gas-chambers of the Third Reich. When the light goes on at the end of the performance, the pile of Barbie-dolls that were thrown off-stage and in front of the audience, reminds us of a mass grave. A heart-rending experience.

\section{Embodied Minds}

Fabre's theatrical aesthetics of intensities is not, however, a theater of sensation, or of plaisir-décharge, as Deleuze calls it. This was confirmed by Stefan Hertmans who described Fabre's stage not as a playground for actors, but as the inside of a skull: 
His [playground] seems a longing to confront us with that imaginary point in time when this strange dichotomy between insanity and identity came into being, the point of origin of this memory of an ecstasy, this brute form of anxiety, this gazing into an absent distance [...]. In the manner of Beuys, his theater challenges the viewer to read the meaning for himself, to interpret ambiguously and, above all, not to succumb to the desire to explain things entirely. [...] Catharsis, moreover, is no longer a matter of the development of action, but of a growing insight into something that has long been an object of contemplation" $(87-88,92)$.

In Deleuzian terms, the spectator is not merely overwhelmed by affects that are part of an aesthetics of sensation. A Deleuzian aesthetics of intensities is a neuroaesthetics in the sense that a new kind of brain is required; "either to create new connections, new linkages, or vital 'transmitters' in the brain" (Rajchman 136).

In this Deleuzian sense, affects are "not to be confused with personal feelings, [...] [percepts] are not to be confused with objects given to a perceiving subject. [...] affects go beyond the subjects that pass through them, and they are impersonal, even inhuman; and percepts are not ways of presenting nature to the eye, but are rather like landscapes, urban as well as natural, in which one must lose oneself so as to see with new eyes" (Rajchman 134-135). Affects and percepts do not grasp what can also be grasped by the other faculties (imagination, memory, understanding and reason). The spectators strive to comprehend theses sensations in their totality, but they are unable to do so. Common sense is confronted with its own limits. Rather than have all the faculties harmoniously united in an act of recognition, Fabre lets each faculty confront its own differential limit. This 'discordant accord' between the demands of reason, the encountered signaletic material and the faculty of sensibility, testifies to the 'unrepresentable', the 'invisible', the 'inaccessible', the 'indescribable'; it testifies to difference.

Fabre rescues the signaletic material from enclosure in representation, or its subordination to the subject of representation. We find ourselves in a kind of amorphous or unformed, ungrounded space, in a landscape formed by an asymmetrical synthesis of the sensible. By presenting this landscape to the spectator, Fabre extracts percepts and affects from habitual sensibilia - "from habits of perception, memory, recognition, agreement" - and makes us see, feel and think in new or unforeseen ways, especially as far as the human body is concerned. From this encounter with this landscape, the spectator emerges "refreshed as if endowed with a new optic or nervous system" (Rajchman 135) and new bodyscapes emerge.

This brings me back to the words of the actress Anny Czupper who, at the beginning of the performance, shouts words of Ulrike Meinhof out loud: "You have given me the harshest punishment: solitary confinement in a prison that is perfectly clinical, cold, and antiseptic. Like the waiting-room of death. In this prison, you subject me to the most perverse torture: sensorial deprivation." These words are not only a political statement in the post-representative meaning of the word, but also and at the same time a defence of an aesthetics of intensities, of a revaluation of the faculty of sensibility, of a multi-perspectivist and sensorial-associative way of making theater: 
This performance has become a political statement, but in a way that it does not depend on mechanisms of identification, in a negative or positive way (the good and the bad), but on confrontation. I see too many performances testifying to a kind of socio-liberal behaviour that is honest and responsible, but at the same time very self-complacent. I call this kind of theater 'design'. It does not derange, it fits anywhere and it is perfectly innocent. I don't want to do that! (Fabre, As Long as s.p)

Fabre himself can be considered a warrior of beauty in the field of contemporary performing arts.

\section{Works cited}

Bacon, Francis. The Brutality of Fact: Interviews with David Sylvester. London: Thames and Huston, 1975.

Bensamaïa, Réda, Toufic, Jalal. “Recommending Deleuze - in 1998!” Discourse: journal for theoretical studies in media and culture, 20 (1998) 3: 4-16.

Bousset, Sigrid. "Befriended Texts." Jan Fabre: Texts on bis Theatre Work. Ed. Sigrid Bousset. Brussels: Kaaitheater, 1993. 9-11.

Braidotti, Rosi. Patterns of Dissonance: a Study of Women in Contemporary Pbilosopby. Cambridge: Polity Press, 1996.

Carter, Curtis L. "Beyond Performance: re Jan Fabre." Jan Fabre: Texts on his Theatre-Work. Ed. Sigrid Bousset. Brussels: Kaaitheater, 1993. 13-26.

Deleuze, Gilles. Différence et répétition. Paris: Presses Universitaires de France, 1968.

Deleuze, Gilles. Spinoza - philosopbie pratique. Paris: Les Editions de Minuit, 1981.

Deleuze, Gilles. "Désir et plaisir." Magazine littéraire Oct. 1994: s.p. (Les inédits du Magazine littéraire)

Deleuze, Gilles. Guattari, Félix. Mille Plateaux. University of Minnesota press, 1987.

Deleuze, Gilles, Rabinow, P., Gandal, K. "The Intellectual and Politics: an Interview with Gilles Delcuze." History of the Present 2(1986)1-2: 20-21.

Descartes, R. "Meditations on First Philosophy." The Pbilosophical Works of Descartes. Ed. E.S. Haldane and G.R.T. Ross, 2 vols. Reprint, Cambridge: Cambridge University Press, [1641] 1970.

Fabre, Jan. Homo Fabre. Bornem: Ter Dilft, Bornem Cultural Centre, Exhibition Catalogue, 1981.

Fabre, Jan, Adolphe, Jean-Marc, Tratsaert, Hendrik; "Gesprek met Jan Fabre.” Mouvement July-September 2000, printed in the theatre programme As long as the world needs a warrior's soul, premiered on Wednesday 18 October 2000, at De Singel in Antwerp.

Foucault, Michel. Histoire de la sexualité. vol. 1. La volonté de savoir. Paris: Editions Gallimard, 1976.

-. "The History of Sexuality." Michel Foucault: Power/Knowledge. Ed. C. Gordon. Brighton: Harvester, 1980. 183-193.

Foucault, Michel, Deleuze, Gilles. "Michel Foucault en Gilles Deleuze: gesprek over intellektuelen en de macht." Raster. 10 (1979): 133.

Gatens, Moira. "Through a Spinozist Lens: Ethology, Difference, Power." Deleure: a Critical Reader. Ed. Paul Patton. Oxford: Blackwell Publishers, 1997. 162-187. 
Hertmans, Stefan. "Morality and the Anonymous: Emblematic Aspects in the Work of Jan Fabre." Jan Fabre: Texts on his Theatre Work. Ed. Sigrid Bousset. Brussels: Kaaitheater, 1993. 81-93.

Jameson, Fredric. Postmodernism, or the Cultural Logic of Late Capitalism. London: Verso, 1991.

Lakoff, George, Johnson, Mark. Philosopby in the Flesh: the Embodied Mind and its Challenge to Western Thought. New York: Basic Books, 1999.

Patton, Paul. "Introduction." Deleuge: a Critical Reader. Ed. Paul Patton. Oxford: Blackwell Publishers, 1997. 1-17.

Rajchman, John. The Deleuze Connections. Cambridge (Massachusetts): The Massachusetts Institute of Technology Press, 2000.

Rodowick, D. N. Gilles Deleuze's time-machine. Durham: Duke University Press, 1997.

Smith, Daniel W. "Deleuze's Theory of Sensation: Overcoming the Kantian Duality." Deleuze: a Critical Reader. Ed. Paul Patton. Oxford: Blackwell Publishers, 1997. 29-56.

Tratsaert, Hendrik. "Het lichaam in opstand: over het maken en sturen van As long as the world needs a warrior's soul.", 'Theatre programme As long as the world needs a warrior's soul, premiered on Wednesday 18 October 2000, at De Singel in Antwerp. 